\title{
Effect of Salt Stress on Some Biochemical and Hormonal Parameters of Pregnant Shami Goats and Their Growing Kids under Semi-Arid Conditions
}

\section{Moharram Fouad El-Bassiony*, Ahmed Sobhi El-Hawy, Ashgan Mohamed El-Lamei, Reda Abd-Ellattif Abd-Elazem}

\author{
Animal and Poultry Physiology Department, Animal and Poultry Production Division, Desert Research Center, \\ Mataria, 11753, Cairo, Egypt.
}

\begin{abstract}
This study aimed at investigating the effect of drinking saline water and feeding salt tolerant plant on some physiological parameters of pregnant Shami goats and their offspring. Forty late pregnant goats (at $4^{\text {th }}$ and $5^{\text {th }}$ months of pregnancy) were randomly divided into 2 groups $\left(20\right.$ each). The $1^{\text {st }}$ group (control; C) was fed a diet consisted of concentrate feed mixture (CFM) plus berseem hay and drank fresh tap water (274 ppm TDS). The $2^{\text {nd }}$ group (S) was fed CFM plus Alfalfa and drank saline water (6000 ppm TDS). The treatment lasted to the weaning of their kids at 90 days of age. Body weight gain was significantly lower in females of S group than in control ones. Similar trend was observed in kids body weight gain from birth tell weaning. Total plasma proteins of pregnant Shami does were not affected by salt intake, but decreased with advancing pregnancy in females of the two experimental groups. Kids of $\mathrm{S}$ group had higher $(\mathrm{P}<0.05)$ levels of all plasma proteins than found in kids of $\mathrm{C}$ group. Total lipids and insulin decreased $(\mathrm{P}<0.05)$ by salt intake in pregnant goats and their kids. Leptin decreased $(\mathrm{P}<0.05)$ in pregnant does of $\mathrm{S}$ group but not in their kids. Liver and kidney functions indicators significantly increased in both does and their kids of group S. Blood electrolytes $(\mathrm{Na}$ and $\mathrm{K}$ ) and plasma osmolality increased significantly in does drank saline water and their kids which have negative feedback on aldosterone. In conclusion, Shami goats can tolerate a high salt intake and living under harsh condition of marginal regions with minimum weight loss. Their offspring will be programmed to alter their adaptive response to grow well under these harsh conditions.
\end{abstract}

Keywords | Salt tolerant, Shami goats, Maternal, Biochemical, Hormones.

Received | June 10, 2020; Accepted | June 21, 2020; Published | August 03, 2020

*Correspondence | Moharram Fouad El-Bassiony, Animal and Poultry Physiology Department, Animal and Poultry Production Division, Desert Research Center, Mataria, 11753, Cairo, Egypt; Email: moharramf@yahoo.com

Citation | El-Bassiony MF, El-Hawy AS, El-Lamei AM, Abd-Elazem RAE (2020). Effect of salt stress on some biochemical and hormonal parameters of pregnant shami goats and their growing kids under semi-arid conditions. Adv. Anim. Vet. Sci. 8(9): 940-950.

DOI | http://dx.doi.org/10.17582/journal.aavs/2020/8.9.940.950

ISSN (Online) | 2307-8316; ISSN (Print) | 2309-3331

Copyright $(\odot) 2020$ El-Bassiony et al. This is an open access article distributed under the Creative Commons Attribution License, which permits unrestricted use, distribution, and reproduction in any medium, provided the original work is properly cited.

\section{INTRODUCTION}

Shortage of feed resources and salinity of water are com$\mathcal{O}_{\text {mon characteristics in marginal regions of desert areas }}$ and it is considered the main constraints to improve livestock productivity. The use of alternative feed resources from salt tolerant plants was proved to be useful in these regions (E1-Shaer, 2006; 2010; Fayed et al., 2010). However, high salt intakes through feed stuffs or water decrease ruminant's productivity. Nevertheless, small ruminants could cope against these harsh conditions. Martin-Gronert (2006) found that adaptive responses such as alternation in water intake and hormonal changes could adapt pregnant ewes to a high dietary salt intake. He added that when high salt intake comes from feed alone, and there is an unlimited supply of freshwater, the animal can cope by increasing water intake and therefore increasing the salt excreting capacity by the kidneys. In pregnant ewes, Digby et al. (2008) found that the consumption of a $13 \% \mathrm{NaCl}$ diet causes a decrease in aldosterone concentration reached 
about two-folds.

During suckling period, new born kids depend basiclly on their mother in feeding, and this may be in turn a good reason for inhancing the adaptive responses to the most of the outside challenges especially salinity problems which become very crucial (Digby et al., 2010). Parental growth is sensitive to the direct and indirect effects of maternal dietary intake which may cause behavioural (e.g. diet selection and intake; Curtis et al., 2004) and physiological (the renin-angiotensin system and renal function; Digby et al., 2010) changes later life of the offspring. Moreover, the previous authors reported also that the fetal hormonal systems which control salt and water balance could be modified by high-salt intake during pregnancy. Reprogramming occurs to fetal renin-angiotensin system that liable for the upkeep of water and salt balance, with aldosterone controlling the retention of sodium and arginine vasopressin that controls water reabsorption by the kidney. Accordingly, offspring could be more tolerant to salt stress. In cattle, calves had a better appetite for sodium when their dams received sodium supplement $(70 \mathrm{~g} \mathrm{NaCl} /$ day $)$ during the last two months of pregnancy (Mohamed and Phillips, 2003).

There is a lack in knowledge about growth performance and metabolic profile of kids that born to goats ingest high salt amount during pregnancy. Therefore, the main objective of this study was to reveal the effect of high salt intake by pregnant Shami does on the performance of their offspring under semi-arid conditions of South Sinai Governorate, Egypt, as marginal region.

\section{MATERIAL AND METHODS}

\section{EXPERIMENTAL REgION}

This study was carried out at South Sinai Research Station (Ras Sudr), belongs to Desert Research Center, South Sinai Governorate, Egypt. The experiment aimed at assessing the impact of high salt intake at late pregnancy on some physiological responses of Shami does and their offspring tell weaning.

\section{ETHICAL ApPROVAL}

This experiment was performed according to all ethics and animal rights (Desert Research Center). As much as this work had considering all rules and regulations in conformity with the European union directive for the protection of experimental animals (2010/63/EU).

\section{Experimental Design}

Forty Shami female goats aged 3-4 years old with averaged $29.38 \pm 0.32 \mathrm{~kg}$ body weight, were randomly divided into two equal groups (20 each). The first group (C) was fed berseem hay (Trifolium alexandrinum) and drank fresh water (274 ppm of total dissolved salts; TDS) and this group served as a control. The second group (S) was fed on salt-tolerant plants (SP, alfalfa) and drank saline water (6000 ppm TDS). All does were clinically examined then synchronized and naturally mated with bucks of the same breed. Bucks were rotated to eliminate the sire effect. Mating was performed in August, and pregnancy was diagnosed by ultrasonography and confirmed by the birth of the kids after parturition. Once kidding took place, the born kids were identified by ear tag and left with their dams till the end of experiment. Ten kids from each group were chosen for measuring some biochemical and hormonal responses. Experimental periods consisted of 2 intervals, two months pre-partum ( $4^{\text {th }}, 5^{\text {th }}$ months $)$ and the first four months of age for their kids. Live body weight of ewes and their offspring were recorded monthly.

\section{Experimental FeEding ANd MANagement}

All experimental animals were fed their nutrient requirements from roughages (berseem hay or alfalfa) and concentrate feed mixture (CFM) (40:60) to cover their maintenance and productive requirements according to Kearl (1982). The CFM consisted of $25 \%$ decorticated cotton seed meal,43\% yellow corn, $25 \%$ wheat bran, $3.5 \%$ molasses, $2 \%$ limestone, $1 \%$ common salt and $0.5 \%$ minerals mixtures and vitamins. Samples from roughage and CFM were taken monthly to determine their chemical composition according to the standard methods of A.O.A.C. (1995). Salt-tolerant plant (Alfalfa) contained higher crude protein, ether extract, nitrogen free extract but lower crude fiber and Ash (18.8, 2.5, 50.5, 20.6 and 7.6\%, respectively) than that in berseem hay $(17.5,1.4,41.3,28.2$ and $11.6 \%$, respectively). The corresponding values for CFM were $14.2,3.4,69.7,8.1$ and $4.6 \%$, respectively.

Saline water (SW) had higher values of total dissolved solids $(6000 \mathrm{mg} / \mathrm{L})$ and electric conductivity $(9.96 \mu \mathrm{s} / \mathrm{cm})$ than those in tap water (TW) $(274 \mathrm{mg} / \mathrm{L}$ and $0.53 \mu \mathrm{s} / \mathrm{cm}$, respectively). Moreover, SW had higher values of all minerals especially sodium, chloride, calcium and magnesium ions $(85.9,61.4,15.1$ and $18.9 \mathrm{mg} / \mathrm{L}$, respectively) than those in TW $(2.4,2.5,1.8$ and $2.3 \mathrm{mg} / \mathrm{L}$, respectively). The $\mathrm{pH}$ values were almost equal in both waters.

\section{Blood Sampling and Measurements}

Jugular blood samples were withdrawn into clean heparinized tubes in early morning just before feeding. Samples from does were taken at $4^{\text {th }}$ and $5^{\text {th }}$ months of pregnancy. Blood samples taken from kids in 60, 90, 120 day of age. No samples were taken at the first month of age to avoid stress. These samples were centrifuged for 15 minutes at 3000 r.p.m. for plasma separation before being stored at $-20^{\circ} \mathrm{C}$ until blood analysis. 
Using commercial kits supplied by Biostc Company for Laboratory Services, Egypt, some blood biochemical parameters were determined for both does and their kids. Those parameters included total proteins (TP), albumin (A), total lipids (TL), total cholesterol (TC), glucose (Glu), urea, blood urea nitrogen (BUN), creatinine (CR), transaminase enzymes (alanine aminotransferase; ALT and aspartate aminotransferase; AST) and blood electrolytes in terms of sodium $(\mathrm{Na})$ and potassium $(\mathrm{K})$. Values of globulin $(\mathrm{G})$ and $\mathrm{A} / \mathrm{G}$ ratio were calculated. In addition, insulin, insulin like growth factor-1 (IGF-1), and leptin hormone were measured by the enzyme-linked immunosorbent assay (ELISA) using CUSABIO ELISA kit (CUSABIO BIOTECH Co. Ltd., College Park, MD. USA). Aldosterone hormone was measured using ready antibody coated tubes kits manufactured by Immunotech, Beckman Counter Company, France.

\section{Statistical Analysis}

Statistical analysis of body weight was carried out using a General Linear Model (GLM) procedures (SAS, 2004) using One-way analysis of variance according to this model: $Y_{i j}=\mu+T_{i}+e_{i j ;}$ Where: $Y_{i j}=$ any observations of $i^{\text {th }}$ animal within $j^{\text {th }}$ treatment. $\mu=$ over all mean; $T_{i}=$ effect of treatment $(\mathrm{i}=1-2) ; \mathrm{e}_{\mathrm{ij}}=$ experimental error.

Statistical analysis of other traits was carried out using a General Linear Model (GLM) procedures (SAS, 2004) using Two-way analysis of variance to test the effects of treatment, age and their interaction according to this model: $Y_{i j k}=\mu+T_{i}+S_{j}+T_{i j}+e_{i j k ;}$ Where: $Y_{i j k}=$ observations value of the $\mathrm{K}^{\text {th }}$ animal; $\mu=$ over all mean; $T_{i}=$ effect of treatment ( $i=1-2) ; S_{j}=$ effect of status period, $(j=1-2$ for ewes) and ( $\mathrm{j}=1-3$ for kids); $\mathrm{TS}_{\mathrm{ij}}=$ interaction between treatment and status period; $\mathrm{e}_{\mathrm{ijk}}=$ experimental error.

Significant differences among means were detected using Duncan's multiple range test (Duncan, 1955).

\section{RESULTS AND DISCUSSION}

\section{Live Body Weight Changes}

During pregnancy, Shami females that drank saline water had lower $(\mathrm{P}<0.05)$ body weight gain $(5.12 \mathrm{~kg})$ than control ones $(6.88 \mathrm{~kg})$ (Table 1). In spite of that, Kids of group $\mathrm{S}$ had higher birth weight than those of control group (2.88 vs. $2.66 \mathrm{~kg}$ ). Birth weight of kids was stated to have a relationship with survivability (Mtenga et al., 1992; Awemu et al., 2002). This might indicate the ability of Shami kids to withstand the harsh conditions of marginal areas. However, treatment affected growth of kids during neonatal period. Kids that were born from does drinking saline water showed less $(\mathrm{P}<0.05)$ weaning weight $(11.58$ vs. $12.84 \mathrm{~kg}$ ) and daily gain (96.66 vs. $113.11 \mathrm{~g} /$ day). Digby et al. (2010) found that feeding goats with high salt intake during pregnancy led to a reduction in feed intake by their offspring. This might suggest that kids' growth rate decreased in the treated group as a result of the reduction in milk intake. Results reached in the present study revealed that kids' weight after one month of weaning (at the $4^{\text {th }}$ month of age) did not statistically differ, which meant that kids of $S$ group could cope the weaning choke such as their counterparts of control group. It could be concluded that Shami kids that were born to does drink saline water were able to physiologically regulate their water and salt balance, hence adapt themselves to the challenge of salt ingestion.

\section{Plasma Proteins}

Treatment had no significant effect on plasma proteins of female goats. In general, goats fed salt tolerant plant and drank saline water at late pregnancy period $\left(4^{\text {th }}\right.$ and $5^{\text {th }}$ month) had a slightly lower concentration of total proteins, albumin, globulin and albumin/globulin ratio $(\mathrm{A} / \mathrm{G})$ than the control ones (Table 2). Abdel-Halim (2003) and Shaker et al. (2014) recorded similar results. Coles (1986) explained that the reduction of plasma proteins in animals due to high salt intake might be due to poor absorption of dietary constituents from the intestinal tract lead to hypoproteinemia.

Total proteins decreased $(\mathrm{P}<0.05)$ with advancing pregnancy, and this was more obvious in control female goats. This decrease in control does were due to decrease in both albumin and globulin. During the same period, treated does showed a decrease in plasma albumin (4.82 to $4.42 \mathrm{~g} /$ dl) while globulin increased ( 3.68 to $3.87 \mathrm{~g} / \mathrm{d} 1)$. This what made significant interaction $\operatorname{Tr}^{*} \mathrm{M}$ in most of plasma protein parameters (Table 2). The explanation might be due to the decrease in active transport of amino acids needed for building albumin rather than globulin in hepatic tissue. According to Tata and Widnell (1966) the decline in albumin concentration might reflect reasonable impairment of liver function. This might be true in the present study since both transaminases ALT and AST of treated does increased $(\mathrm{P}<0.05)$ with advancing pregnancy besides being significantly higher than those of control does (Table 6). In different ruminant species, Hussein (1987) and Ibrahim et al. (1991) founded that drinking saline water resulted in an increase in GPT. Also, Ibrahim (1995) working on goats reported that drinking saline water (9178 and $13760 \mathrm{ppm}$ ) increased significantly GPT and insignificantly GOT. Abdel Rahman et al. (2000) suggested that the increase in amino transferases might reflect malfunction of the liver, which was supported by the plasma albumin decrease after drinking saline water. This indicated that does drank saline water during pregnancy suffered physiological problems.

Both groups of kids showed decrease in all types of plasma proteins from $2^{\text {nd }}$ to $3^{\text {rd }}$ month of age. However, after wean 
Table 1: Effect of salt stress on body weight changes of pregnant Shami goats and their kids

\begin{tabular}{|c|c|c|c|}
\hline \multirow[t]{2}{*}{ Items } & \multicolumn{2}{|c|}{ Treatment } & \multirow[t]{2}{*}{ \pm SE } \\
\hline & $\mathrm{C}$ & $\mathbf{S}$ & \\
\hline \multicolumn{4}{|l|}{ Body weight changes of does: } \\
\hline Body weight $(\mathrm{Kg})$ at start of pregnancy & 29.66 & 29.10 & 0.47 \\
\hline Weight just before kidding $(\mathrm{Kg})$ & $44.16^{\mathrm{a}}$ & $41.24^{\mathrm{b}}$ & $0.67^{*}$ \\
\hline Weight gain during pregnancy $(\mathrm{Kg})$ & $6.88^{\mathrm{a}}$ & $5.12^{\mathrm{b}}$ & 0.31 \\
\hline \multicolumn{4}{|l|}{ Growth performance of suckling kids: } \\
\hline Birth weight $(\mathrm{Kg})$ & 2.66 & 2.88 & 0.28 \\
\hline Weaning weight at 90 days of age $(\mathrm{Kg})$ & $12.84^{\mathrm{a}}$ & $11.58^{\mathrm{b}}$ & $0.41^{*}$ \\
\hline Daily weight gain (g/day) & $113.11^{\mathrm{a}}$ & $96.66^{\mathrm{b}}$ & $2.63^{*}$ \\
\hline Weight $(\mathrm{Kg})$ after one month of weaning (120 day) & 15.47 & 14.69 & 0.63 \\
\hline
\end{tabular}

C: fed on berseem hay and drank tap water, S: fed on alfalfa and drank saline water, ${ }^{a, b}$ Means bearing different superscripts within the same row are significantly different $(\mathrm{P}<0.05)$.

Table 2: Plasma proteins concentrations of pregnant Shami goats as affected by salt stress

\begin{tabular}{|c|c|c|c|c|c|c|c|}
\hline \multirow[t]{2}{*}{ Items } & \multirow[t]{2}{*}{ Month of pregnancy } & \multicolumn{2}{|c|}{ Treatment (Tr) } & \multirow{2}{*}{$\begin{array}{l}\text { Overall } \\
\text { mean }\end{array}$} & \multicolumn{3}{|l|}{$\pm \mathrm{SE}$} \\
\hline & & $\mathrm{C}$ & $\mathbf{S}$ & & $\operatorname{Tr}$ & M & $\operatorname{Tr}^{*} \mathbf{M}$ \\
\hline \multirow[t]{2}{*}{$\mathrm{TP}(\mathrm{g} / \mathrm{dl})$} & $4^{\text {th }}$ & 9.30 & 8.50 & $8.90^{\mathrm{A}}$ & \multirow[t]{3}{*}{$0.09^{\mathrm{NS}}$} & \multirow[t]{3}{*}{$0.09^{*}$} & \multirow[t]{3}{*}{$0.13^{*}$} \\
\hline & $5^{\text {th }}$ & 8.58 & 8.40 & $7.99^{\mathrm{B}}$ & & & \\
\hline Overall mean & & 8.94 & 8.45 & & & & \\
\hline \multirow[t]{2}{*}{ Albumin (g/dl) } & $4^{\text {th }}$ & 5.12 & 4.82 & $4.97^{\mathrm{A}}$ & \multirow[t]{3}{*}{$0.15^{\mathrm{NS}}$} & \multirow[t]{3}{*}{$0.15^{*}$} & \multirow[t]{3}{*}{$0.21^{\mathrm{NS}}$} \\
\hline & $5^{\text {th }}$ & 4.92 & 4.52 & $4.42^{\mathrm{B}}$ & & & \\
\hline Overall mean & & 5.02 & 4.67 & & & & \\
\hline \multirow[t]{2}{*}{ Globulin (g/dl) } & $4^{\text {th }}$ & 4.18 & 3.68 & 3.93 & \multirow[t]{3}{*}{$0.12^{\mathrm{NS}}$} & \multirow[t]{3}{*}{$0.12^{\mathrm{NS}}$} & \multirow[t]{3}{*}{$0.17^{*}$} \\
\hline & $5^{\text {th }}$ & 3.66 & 3.87 & 3.56 & & & \\
\hline Overall mean & & 3.92 & 3.77 & & & & \\
\hline \multirow[t]{2}{*}{$\mathrm{A} / \mathrm{G}$ ratio } & $4^{\text {th }}$ & 1.22 & 1.33 & 1.28 & \multirow[t]{3}{*}{$0.07^{\mathrm{NS}}$} & \multirow[t]{3}{*}{$0.07^{\mathrm{NS}}$} & \multirow[t]{3}{*}{$0.10^{*}$} \\
\hline & $5^{\text {th }}$ & 1.35 & 1.19 & 1.26 & & & \\
\hline Overall mean & & 1.28 & 1.26 & & & & \\
\hline
\end{tabular}

ing $\left(4^{\text {th }}\right.$ month of age $)$ all kids showed obvious increase in all these proteins. In all cases, kids of group $\mathrm{S}$ had significant higher values of plasma total proteins, albumin and globulin than kids of $\mathrm{C}$ group (Table 3). Female goats of $\mathrm{S}$ group fed the salt tolerant plant Alfalfa. This plant contains higher crude protein, ether extract and nitrogen free extract than berseem hay, which might help in producing milk that have higher protein content during suckling period. Accordingly, kids of this group obtained more protein that help in building higher amounts of plasma albumin and globulins. This might indicate the capability of Shami kids; that born to does exposed to saline stress; to withstand the harsh conditions and saline stress prevailing in the marginal regions.

\section{Metabolic Energy Indicators}

Pregnant goats fed on salt tolerant plant and drank saline water showed significant lower total lipids, insulin and leptin as compared to their control counterparts. This was accompanied with insignificant increase in glucose, cholesterol and IGF-1 (Table 4). High salt intake has been shown to regulate energy partitioning in sheep including a direct effect on insulin concentration, as much as, this reduction in insulin concentration as a result of feeding high-salt diet is unrelated to the decrease in feed intake (Blache et al., 2007). Those authors explained that this in turn led to an increase in the high density lipoproteins (HDLs) which contain cholesterol. This relation can be seen as an indicator of the animal's energy status.

Lower leptin concentrations due to salt intake during pregnancy might suggest an effect of 'salt programming' on leptin and increased the energy expenditure, as much as this ingestion of high salt intake may resulted in mobilization of energy reserves (Digby et al., 2008). Furthermore, 
Table 3: Plasma proteins concentrations of kids born to pregnant goats ingest high salt intake.

\begin{tabular}{|c|c|c|c|c|c|c|c|}
\hline \multirow[t]{2}{*}{ Items } & \multirow{2}{*}{$\begin{array}{l}\text { Age } \\
\text { (month) }\end{array}$} & \multicolumn{2}{|c|}{ Treatment (Tr) } & \multirow{2}{*}{$\begin{array}{l}\text { Overall } \\
\text { mean }\end{array}$} & \multicolumn{3}{|l|}{$\pm \mathrm{SE}$} \\
\hline & & C & $\mathbf{S}$ & & $\operatorname{Tr}$ & $\mathbf{M}$ & $\operatorname{Tr}^{*} \mathbf{M}$ \\
\hline \multirow[t]{3}{*}{$\mathrm{TP}(\mathrm{g} / \mathrm{dl})$} & $2^{\text {nd }}$ & 4.85 & 6.14 & 5.50 & \multirow[t]{3}{*}{$0.08^{*}$} & \multirow[t]{3}{*}{$0.09^{\mathrm{NS}}$} & \multirow[t]{3}{*}{$0.14^{\mathrm{NS}}$} \\
\hline & $3^{\text {rd }}$ & 4.72 & 6.10 & 5.41 & & & \\
\hline & $4^{\text {th }}$ & 5.12 & 6.10 & 5.61 & & & \\
\hline Overall mean & & $4.90^{b}$ & $6.11^{\mathrm{a}}$ & & & & \\
\hline \multirow[t]{3}{*}{ Albumin (g/dl) } & $2^{\text {nd }}$ & 3.28 & 4.21 & $3.75^{\mathrm{AB}}$ & \multirow[t]{3}{*}{$0.10^{*}$} & \multirow[t]{3}{*}{$0.12^{*}$} & \multirow[t]{3}{*}{$0.17^{\mathrm{NS}}$} \\
\hline & $3^{\text {rd }}$ & 3.24 & 3.77 & $3.51^{\mathrm{B}}$ & & & \\
\hline & $4^{\text {th }}$ & 3.52 & 4.49 & $4.01^{\mathrm{A}}$ & & & \\
\hline Overall mean & & $3.35^{\mathrm{b}}$ & $4.16^{\mathrm{a}}$ & & & & \\
\hline \multirow[t]{3}{*}{ Globulin (g/dl) } & $2^{\text {nd }}$ & 1.57 & 1.93 & 1.75 & \multirow[t]{3}{*}{$0.10^{*}$} & \multirow[t]{3}{*}{$0.13^{\mathrm{NS}}$} & \multirow[t]{3}{*}{$0.18^{\mathrm{NS}}$} \\
\hline & $3^{\text {rd }}$ & 1.48 & 2.33 & 1.91 & & & \\
\hline & $4^{\text {th }}$ & 1.60 & 1.61 & 1.60 & & & \\
\hline Overall mean & & $1.55^{\mathrm{b}}$ & $1.95^{\mathrm{a}}$ & & & & \\
\hline \multirow[t]{3}{*}{$\mathrm{A} / \mathrm{G}$ ratio } & $2^{\text {nd }}$ & 2.12 & 2.28 & $2.20^{\mathrm{AB}}$ & \multirow[t]{3}{*}{$0.17^{\mathrm{NS}}$} & \multirow[t]{3}{*}{$0.21^{*}$} & \multirow[t]{3}{*}{$0.30^{\mathrm{NS}}$} \\
\hline & $3^{\text {rd }}$ & 2.20 & 1.75 & $1.97^{\mathrm{B}}$ & & & \\
\hline & $4^{\text {th }}$ & 2.42 & 2.97 & $2.70^{\mathrm{A}}$ & & & \\
\hline $\begin{array}{l}\text { Overall mean } \\
\text { C: fed on berseen } \\
\text { superscripts withir }\end{array}$ & $0-1)$ & $\begin{array}{l}2.24 \\
\text { ed on }\end{array}$ & $\begin{array}{l}2.33 \\
\text { lerant }\end{array}$ & $1: \rho$ & & $D 1$ & , \\
\hline
\end{tabular}

Briffa et al. (2015) clarified that in all species, there is a plasma leptin surge that occurs during pregnancy (humans) or postnatally during the suckling period (other mammals) that is correlated with the maturation and development of the organ. Fetus development may influenced by the changes in maternal-placental-fetal leptin modification. Accordingly, the lower $(\mathrm{P}<0.01)$ value of leptin of saline stressed does (Table 4$)$ resulted in lower $(\mathrm{P}<0.05)$ weaning weight of their offspring (Table 1).

In pregnant goats, insulin and leptin take the same trend where they decreased with advancing pregnancy (Table 4). Tokuda et al. (2001) and Magistrelli et al. (2008) stated that during periods of negative energy balance there was a reduction in serum leptin. This interpret the highly significant decrease in leptin in pregnant goats in the $5^{\text {th }}$ month of pregnancy. In accordance, cholesterol level was significantly rises in the $5^{\text {th }}$ month of pregnancy and this might be due to the increase of stress on pregnant does at this stage (pre-partum) which need more energy.

Insulin growth factor-1 (IGF-1) is a primary mediator of the effects of growth hormone and stimulates the growth-promoters in nearly every cell in the body (Scarth, 2006). In the present study, IGF-1 insignificantly increased with advancing pregnancy (from 89.80 to 92.24 $\mathrm{ng} / \mathrm{ml})$. This might be a response for fetal growth. It worth notice that does drank saline water had insignificant higher values of IGF-1 than control ones (92.24 vs. $90.48 \mathrm{ng} /$ $\mathrm{ml}$ ) that might interpret the higher birth weight of their kids (Table 1).

The offspring born to does fed Alfalfa and drank saline water during pregnancy (S group) had significant lower total lipids and insulin, but higher cholesterol than their counterparts of group C (Table 5). Coincidently, they had insignificantly higher glucose. Both leptin and IGF-1 did not affected by treatment.

Blache et al. (2007) explained that high salt feeding during pregnancy is associated with changes in circulating concentration of insulin, leptin, and thyroid hormones. These changes might have effects on offspring. Digby et al. (2008) stated that alternation in ewes' thyroid hormone concentrations could affect lambs' birth weight. Moreover, Digby et al. (2010) suggested that the biology of the offspring is influenced mainly by the ingestion of high-salt intake during pregnancy.

All these parameters, except glucose, were significantly affected by age but in different manners. Total lipids and insulin decreased $(\mathrm{P}<0.01)$ with age, while cholesterol, IGF1 and leptin significantly increased with age. These results indicated that the need of energy to offspring increased with age thus the cholesterol concentration significantly increased in the $4^{\text {th }}$ month at the same time total lipids concentration tended to be significantly decreased. Also, 
Table 4: Effect of salt stress on metabolic energy indicators of pregnant Shami goats

\begin{tabular}{|c|c|c|c|c|c|c|c|}
\hline \multirow[t]{2}{*}{ Items } & \multirow{2}{*}{$\begin{array}{l}\text { Month of } \\
\text { pregnancy }\end{array}$} & \multicolumn{2}{|c|}{ Treatment (Tr) } & \multirow{2}{*}{$\begin{array}{l}\text { Overall } \\
\text { mean }\end{array}$} & \multicolumn{3}{|l|}{$\pm \mathrm{SE}$} \\
\hline & & $\mathrm{C}$ & $\mathbf{S}$ & & $\operatorname{Tr}$ & $\mathbf{M}$ & $\operatorname{Tr}^{*} \mathbf{M}$ \\
\hline \multirow[t]{2}{*}{ Glucose (mg/dl) } & $4^{\text {th }}$ & 53.74 & 55.10 & 54.42 & $1.40^{\mathrm{NS}}$ & $1.40^{\mathrm{NS}}$ & $1.98^{\mathrm{NS}}$ \\
\hline & $5^{\text {th }}$ & 48.31 & 52.54 & 50.43 & & & \\
\hline Overall mean & & 51.02 & 53.82 & & & & \\
\hline \multirow{2}{*}{$\begin{array}{l}\text { Total lipids } \\
\text { (mg/dl) }\end{array}$} & $4^{\text {th }}$ & 426.40 & 280.20 & 371.30 & $11.66^{*}$ & $11.66^{\mathrm{NS}}$ & $16.50^{\mathrm{NS}}$ \\
\hline & $5^{\text {th }}$ & 488.70 & 300.40 & 394.55 & & & \\
\hline Overall mean & & $475.55^{\mathrm{a}}$ & $290.30^{b}$ & & & & \\
\hline \multirow{2}{*}{$\begin{array}{l}\text { cholesterol } \\
\text { (mg/dl) }\end{array}$} & $4^{\text {th }}$ & 84.00 & 96.20 & $90.10^{\mathrm{B}}$ & $4.96^{\mathrm{NS}}$ & $4.96^{*}$ & $7.02^{\mathrm{NS}}$ \\
\hline & $5^{\text {th }}$ & 114.28 & 117.40 & $115.84^{\mathrm{A}}$ & & & \\
\hline Overall mean & & 99.14 & 106.80 & & & & \\
\hline \multirow[t]{2}{*}{ Insulin $(\mu \mathrm{U} / \mathrm{ml})$} & $4^{\text {th }}$ & 30.18 & 26.07 & 28.12 & $0.54^{* *}$ & $0.35^{\mathrm{NS}}$ & $0.75^{\mathrm{NS}}$ \\
\hline & $5^{\text {th }}$ & 28.12 & 25.45 & 26.78 & & & \\
\hline Overall mean & & $29.15^{\mathrm{a}}$ & $25.76^{b}$ & & & & \\
\hline \multirow[t]{2}{*}{ IGF-1 (ng/ml) } & $4^{\text {th }}$ & 88.26 & 89.80 & 89.03 & $1.14^{\mathrm{NS}}$ & $1.13^{\mathrm{NS}}$ & $1.61^{\mathrm{NS}}$ \\
\hline & $5^{\text {th }}$ & 90.48 & 92.24 & 91.36 & & & \\
\hline Overall mean & & 89.37 & 91.02 & & & & \\
\hline \multirow[t]{2}{*}{ Leptin (ng/ml) } & $4^{\text {th }}$ & 2.96 & 2.04 & $2.50^{\mathrm{A}}$ & $0.08^{* *}$ & $0.07^{* * *}$ & $0.11^{\mathrm{NS}}$ \\
\hline & $5^{\text {th }}$ & 1.99 & 1.50 & $1.74^{\mathrm{B}}$ & & & \\
\hline Overall mean & & $2.48^{a}$ & $1.77^{\mathrm{b}}$ & & & & \\
\hline
\end{tabular}

C: fed on berseem hay and drank tap water, S: fed on salt-tolerant plant and drank saline water, IGF-1 = Insulin like growth factor -1 ; A, B Means bearing different superscripts within the same column are significantly different $(\mathrm{P}<0.05)$, ${ }^{\mathrm{a}, \mathrm{b}}$ Means bearing different superscripts within the same rows are significantly different $(\mathrm{P}<0.05), \mathrm{NS}=$ non-significant, ${ }^{*}=$ significant differences $(\mathrm{P}<0.05),{ }^{* *}=$ significant differences $(\mathrm{P}<0.01)$.

insulin has an important role in lipid metabolism, stimulating lipogenesis and inhibiting lipolysis (BanTokuda et al., 2007).

Only, there was significant interaction treatment $\mathrm{X}$ age in IGF-1, because it increased with age more pronouncedly in kids of control group. These kids had significant higher daily gain and weaning weight (Table 1). This clarifies the impact of salt feeding during pregnancy in goat that led to lower growth rate of the offspring after postpartum. Leptin increased with age in the same manner in kids of the two groups that mean it was not affected by salt feeding of mothers during pregnancy.

\section{LiVER AND KidNEy FunCTiONS}

Female Shami goats that fed Alfalfa and drank saline water had significant higher alanine aminotransferase (ALT), aspartate aminotransferase (AST), creatinine, urea and blood urea nitrogen (BUN) as compared to the control group (Table 6). Increasing these parameters was suggested by Flores (2002) and Kaneko (1989) to indicate liver tissue damage and the state of glomerular filtration rate and kidney function. This means that liver and kidney functions had been affected in pregnant goats as a result of salinity. Also, all these parameters except creatinine increased with advancing pregnancy. Goats of group S suffered double stress of pregnancy and salt intake.

Changes in these parameter in offspring take the same trend as their mothers (Table 7), indicating that high salt intake leads to increase liver and kidney functions and suggested that maternal salt intake may affect liver and renal development in the fetus.

These results are in harmony with those reported by E1Tayeb (2006) who found that the activity of liver and kidney enzymes were significantly higher in Nubian goats drank saline water than those drank fresh water. As much as, Fayed et al. (2010) reached the same results in Barki sheep fed salt-tolerant alfalfa compared to control group fed berseem hay.

\section{Minerals Regulation}

Female pregnant Shami goats fed Alfalfa and drank saline water had significant higher values of sodium, potassium, osmolality and renin, but lower $(\mathrm{P}<0.01)$ aldosterone (Table 8). Salt stress disturbed mineral balance and fluid osmolality of pregnant Shami does. Minerals play an im portant role in the regulation of body fluids, acid base balance and metabolic processes (Milne, 1996). Sodium and potassium are of particular importance to the living animal 
Table 5: Metabolic energy indicators of kids born to pregnant goats ingest high salt intake.

\begin{tabular}{|c|c|c|c|c|c|c|c|}
\hline \multirow[t]{2}{*}{ Items } & \multirow{2}{*}{$\begin{array}{l}\text { Age } \\
\text { (month) }\end{array}$} & \multicolumn{2}{|c|}{ Treatment $(\mathrm{Tr})$} & \multirow{2}{*}{$\begin{array}{l}\text { Overall } \\
\text { mean }\end{array}$} & \multicolumn{3}{|l|}{$\pm \mathrm{SE}$} \\
\hline & & C & $\mathbf{S}$ & & $\operatorname{Tr}$ & $\mathbf{M}$ & $\operatorname{Tr}^{*} \mathbf{M}$ \\
\hline \multirow[t]{3}{*}{ Glucose (mg/dl) } & $2^{\text {nd }}$ & 53.80 & 54.61 & 54.20 & \multirow[t]{3}{*}{$1.24^{\mathrm{NS}}$} & \multirow[t]{3}{*}{$1.52^{\mathrm{NS}}$} & \multirow[t]{3}{*}{$2.15^{\mathrm{NS}}$} \\
\hline & $3^{\text {rd }}$ & 53.50 & 55.30 & 54.40 & & & \\
\hline & $4^{\text {th }}$ & 53.84 & 55.59 & 54.72 & & & \\
\hline Overall mean & & 53.71 & 55.17 & & & & \\
\hline \multirow{3}{*}{$\begin{array}{l}\text { Total lipids } \\
(\mathrm{mg} / \mathrm{dl})\end{array}$} & $2^{\text {nd }}$ & 495.40 & 280.20 & $387.80^{\mathrm{A}}$ & \multirow[t]{3}{*}{$9.75^{*}$} & \multirow[t]{3}{*}{$11.94^{* * *}$} & \multirow[t]{3}{*}{$16.89^{\mathrm{N}}$} \\
\hline & $3^{\text {rd }}$ & 462.40 & 207.20 & $334.80^{\mathrm{B}}$ & & & \\
\hline & $4^{\text {th }}$ & 488.80 & 213.40 & $351.10^{\mathrm{B}}$ & & & \\
\hline Overall mean & & $482.20^{a}$ & $233.60^{b}$ & & & & \\
\hline \multirow{3}{*}{$\begin{array}{l}\text { Cholesterol } \\
(\mathrm{mg} / \mathrm{dl})\end{array}$} & $2^{\text {nd }}$ & 80.38 & 99.00 & $89.69^{\mathrm{B}}$ & \multirow[t]{3}{*}{$4.47^{*}$} & \multirow[t]{3}{*}{$5.48^{*}$} & \multirow[t]{3}{*}{$7.75^{\mathrm{NS}}$} \\
\hline & $3^{\text {rd }}$ & 77.60 & 107.8 & $92.70^{\mathrm{B}}$ & & & \\
\hline & $4^{\text {th }}$ & 108.02 & 110.80 & $109.41^{\mathrm{A}}$ & & & \\
\hline Overall mean & & $88.67^{b}$ & $105.87^{\mathrm{a}}$ & & & & \\
\hline \multirow[t]{3}{*}{ Insulin $(\mu \mathrm{U} / \mathrm{ml})$} & $2^{\text {nd }}$ & 29.42 & 25.54 & $27.48^{\mathrm{A}}$ & \multirow[t]{3}{*}{$0.33^{* *}$} & \multirow[t]{3}{*}{$0.40^{* *}$} & \multirow[t]{3}{*}{$0.57^{\mathrm{NS}}$} \\
\hline & $3^{\text {rd }}$ & 27.11 & 23.69 & $25.40^{\mathrm{B}}$ & & & \\
\hline & $4^{\text {th }}$ & 28.48 & 24.62 & $26.55^{\mathrm{AB}}$ & & & \\
\hline Overall mean & & $28.33^{\mathrm{a}}$ & $24.61^{b}$ & & & & \\
\hline \multirow[t]{3}{*}{ IGF-1 (ng/ml) } & $2^{\text {nd }}$ & $90.18^{d}$ & $95.60^{\mathrm{bc}}$ & $92.89^{\mathrm{B}}$ & \multirow[t]{3}{*}{$0.65^{\mathrm{NS}}$} & \multirow[t]{3}{*}{$0.79^{* *}$} & \multirow[t]{3}{*}{$1.12^{* *}$} \\
\hline & $3^{\text {rd }}$ & $92.80^{\mathrm{cd}}$ & $92.42^{\mathrm{d}}$ & $92.61^{\mathrm{B}}$ & & & \\
\hline & $4^{\text {th }}$ & $100.05^{\mathrm{a}}$ & $97.38^{\mathrm{ab}}$ & $98.71^{\mathrm{A}}$ & & & \\
\hline Overall mean & & 94.34 & 95.13 & & & & \\
\hline \multirow[t]{3}{*}{ Leptin (ng/ml) } & $2^{\text {nd }}$ & 1.90 & 1.80 & $1.85^{\mathrm{B}}$ & \multirow[t]{3}{*}{$0.07^{\mathrm{NS}}$} & \multirow[t]{3}{*}{$0.09^{*}$} & \multirow[t]{3}{*}{$0.13^{\mathrm{NS}}$} \\
\hline & $3^{\text {rd }}$ & 2.17 & 2.10 & $2.13^{\mathrm{A}}$ & & & \\
\hline & $4^{\text {th }}$ & 2.40 & 2.20 & $2.30^{\mathrm{A}}$ & & & \\
\hline Overall mean & & 2.15 & 2.03 & & & & \\
\hline
\end{tabular}

C: fed on berseem hay and drank tap water, S: fed on salt-tolerant plant and drank saline water, ${ }^{A, B}$ Means bearing different superscripts within the same column are significantly different $(\mathrm{P}<0.05),{ }^{a, b}$ Means bearing different superscripts within the same rows are significantly different $(\mathrm{P}<0.05), \mathrm{NS}=$ non-significant, ${ }^{*}=$ significant differences $(\mathrm{P}<0.05),{ }^{* *}=$ significant differences $(\mathrm{P}<0.01)$.

Table 6: Effect of salt stress on liver and kidney functions of pregnant Shami goats

\begin{tabular}{|c|c|c|c|c|c|c|c|}
\hline \multirow[t]{2}{*}{ Items } & \multirow{2}{*}{$\begin{array}{l}\text { Month of } \\
\text { pregnancy }\end{array}$} & \multicolumn{2}{|c|}{ Treatment (Tr) } & \multirow{2}{*}{$\begin{array}{l}\text { Overall } \\
\text { mean }\end{array}$} & \multicolumn{3}{|l|}{$\pm \mathrm{SE}$} \\
\hline & & C & $\mathbf{S}$ & & $\operatorname{Tr}$ & $\mathbf{M}$ & $\operatorname{Tr}^{*} \mathbf{M}$ \\
\hline \multirow[t]{2}{*}{$\operatorname{ALT}(\mathrm{U} / \mathrm{I})$} & $4^{\text {th }}$ & $5.50^{\mathrm{b}}$ & $4.80^{c}$ & $5.15^{\text {B }}$ & \multirow[t]{3}{*}{$0.12^{*}$} & $0.12^{* *}$ & \multirow[t]{3}{*}{$0.18^{* *}$} \\
\hline & $5^{\text {th }}$ & $5.17^{\mathrm{bc}}$ & $6.69^{\mathrm{a}}$ & $5.932^{\mathrm{A}}$ & & & \\
\hline Overall mean & & $5.34^{\mathrm{b}}$ & $5.74^{\mathrm{a}}$ & & & & \\
\hline \multirow[t]{2}{*}{ AST (U/1) } & $4^{\text {th }}$ & $35.53^{\mathrm{cd}}$ & $43.16^{\mathrm{b}}$ & $39.34^{\mathrm{B}}$ & \multirow[t]{3}{*}{$1.00^{*}$} & \multirow[t]{3}{*}{$1.00^{*}$} & \multirow[t]{3}{*}{$1.42^{\mathrm{NS}}$} \\
\hline & $5^{\text {th }}$ & $37.45^{c}$ & $48.10^{a}$ & $42.77^{\mathrm{A}}$ & & & \\
\hline Overall mean & & $36.49^{b}$ & $45.63^{a}$ & & & & \\
\hline Creatinine & $4^{\text {th }}$ & $0.83^{c}$ & $1.18^{\mathrm{a}}$ & 1.01 & $0.04^{*}$ & $0.04^{\mathrm{NS}}$ & $0.06^{*}$ \\
\hline$(\mathrm{mg} / \mathrm{dl})$ & $5^{\text {th }}$ & $1.11^{\mathrm{a}}$ & $1.06^{\mathrm{ab}}$ & 1.09 & & & \\
\hline Overall mean & & $0.97^{b}$ & $1.12^{\mathrm{a}}$ & & & & \\
\hline \multirow[t]{2}{*}{ Urea (mg/dl) } & $4^{\text {th }}$ & 57.52 & 62.72 & $60.12^{\mathrm{B}}$ & $1.65^{\prime \prime \prime}$ & $1.65^{*}$ & $2.34^{\mathrm{NS}}$ \\
\hline & $5^{\text {th }}$ & 60.18 & 71.88 & $66.03^{\mathrm{A}}$ & & & \\
\hline Overall mean & & $58.85^{b}$ & $67.30^{a}$ & & & & \\
\hline \multirow[t]{2}{*}{ BUN (mg/dl) } & $4^{\text {th }}$ & 26.88 & 29.31 & $28.09^{\mathrm{B}}$ & $0.77^{* *}$ & $0.77^{*}$ & $1.09^{\mathrm{NS}}$ \\
\hline & $5^{\text {th }}$ & 28.12 & 33.58 & $30.85^{\mathrm{A}}$ & & & \\
\hline
\end{tabular}


Overall mean

$27.50^{\mathrm{b}} \quad 31.44^{\mathrm{a}}$

C: fed on berseem hay and drank tap water, S: fed on salt-tolerant plant and drank saline water, ${ }^{\text {A, B }}$ Means bearing different superscripts within the same column are significantly different $(\mathrm{P}<0.05)$, a, b Means bearing different superscripts within the same rows are significantly different $(\mathrm{P}<0.05), \mathrm{NS}=$ non-significant, ${ }^{*}=$ significant differences $(\mathrm{P}<0.05),{ }^{* *}=$ significant differences $(\mathrm{P}<0.01)$.

Table 7: Liver and kidney functions of kids born to pregnant goats ingest high salt intake.

\begin{tabular}{|c|c|c|c|c|c|c|c|}
\hline \multirow[t]{2}{*}{ Items } & \multirow{2}{*}{$\begin{array}{l}\text { Age } \\
\text { (month) }\end{array}$} & \multicolumn{2}{|c|}{ Treatment (Tr) } & \multirow{2}{*}{$\begin{array}{l}\text { Overall } \\
\text { mean }\end{array}$} & \multicolumn{3}{|l|}{$\pm \mathrm{SE}$} \\
\hline & & C & $\mathbf{S}$ & & $\operatorname{Tr}$ & $\mathbf{M}$ & $\operatorname{Tr}^{*} \mathbf{M}$ \\
\hline \multirow[t]{3}{*}{ ALT (U/1) } & $2^{\text {nd }}$ & $4.70^{e}$ & $6.84^{\mathrm{ab}}$ & $5.77^{\mathrm{B}}$ & \multirow[t]{3}{*}{$0.11^{\mathrm{NS}}$} & \multirow[t]{4}{*}{$0.13^{* *}$} & \multirow[t]{3}{*}{$0.19^{* *}$} \\
\hline & $3^{\text {rd }}$ & $6.96^{\mathrm{a}}$ & $6.36^{\mathrm{bc}}$ & $6.66^{\mathrm{A}}$ & & & \\
\hline & $4^{\text {th }}$ & $5.60^{\mathrm{d}}$ & $4.82^{e}$ & $5.21^{\mathrm{C}}$ & & & \\
\hline Overall mean & & $5.75^{\mathrm{a}}$ & $6.00^{a}$ & & & & \\
\hline \multirow[t]{3}{*}{ AST (U/1) } & $2^{\text {nd }}$ & $10.91^{\mathrm{d}}$ & $17.39^{a}$ & $14.15^{\mathrm{B}}$ & \multirow[t]{3}{*}{$0.50^{* *}$} & \multirow[t]{3}{*}{$0.61^{* *}$} & \multirow[t]{3}{*}{$0.86^{*}$} \\
\hline & $3^{\text {rd }}$ & $15.24^{\mathrm{bc}}$ & $17.81^{\mathrm{a}}$ & $16.53^{\mathrm{A}}$ & & & \\
\hline & $4^{\text {th }}$ & $15.84^{\mathrm{ab}}$ & $17.58^{\mathrm{a}}$ & $16.71^{\mathrm{A}}$ & & & \\
\hline Overall mean & & $14.00^{b}$ & $17.59^{\mathrm{a}}$ & & & & \\
\hline Creatinine & $2^{\text {nd }}$ & $0.64^{\mathrm{d}}$ & $0.74^{\mathrm{cd}}$ & $0.69^{\mathrm{B}}$ & $0.03^{* *}$ & $0.40^{* *}$ & $0.05^{*}$ \\
\hline \multirow[t]{2}{*}{$(\mathrm{mg} / \mathrm{dl})$} & $3^{\text {rd }}$ & $0.89^{c}$ & $1.26^{\mathrm{a}}$ & $1.08^{\mathrm{A}}$ & & & \\
\hline & $4^{\text {th }}$ & $0.84^{c}$ & $1.19^{\mathrm{b}}$ & $1.02^{\mathrm{A}}$ & & & \\
\hline Overall mean & & $0.79^{\mathrm{b}}$ & $1.06^{\mathrm{a}}$ & & & & \\
\hline \multirow[t]{3}{*}{ Urea (mg/dl) } & $2^{\text {nd }}$ & 57.84 & 70.20 & $64.02^{\mathrm{A}}$ & $1.19^{* *}$ & $1.46^{* *}$ & $2.07^{\mathrm{NS}}$ \\
\hline & $3^{\text {rd }}$ & 65.26 & 64.60 & $60.33^{\mathrm{AB}}$ & & & \\
\hline & $4^{\text {th }}$ & 51.52 & 62.49 & $57.01^{\mathrm{B}}$ & & & \\
\hline Overall mean & & $55.21^{\mathrm{b}}$ & $65.70^{\mathrm{a}}$ & & & & \\
\hline \multirow[t]{3}{*}{ BUN (mg/dl) } & $2^{\text {nd }}$ & 27.03 & 32.81 & $29.92^{\mathrm{A}}$ & $0.55^{* * *}$ & $0.68^{* *}$ & $0.96^{\mathrm{NS}}$ \\
\hline & $3^{\text {rd }}$ & 26.29 & 30.09 & $28.19^{\mathrm{AB}}$ & & & \\
\hline & $4^{\text {th }}$ & 24.07 & 29.20 & $26.64^{\mathrm{B}}$ & & & \\
\hline Overall mean & & $25.80^{\mathrm{b}}$ & $30.70^{\mathrm{a}}$ & & & & \\
\hline
\end{tabular}

C: fed on berseem hay and drank tap water, S: fed on salt-tolerant plant and drank saline water, ${ }^{A}, \mathrm{~B}, \mathrm{C}$ Means bearing different superscripts within the same column are significantly different $(\mathrm{P}<0.05)$, a, b, c, d, e Means bearing different superscripts within the same rows are significantly different $(\mathrm{P}<0.05), \mathrm{NS}=$ non-significant, ${ }^{*}=$ significant differences $(\mathrm{P}<0.05),{ }^{* *}=$ significant differences $(\mathrm{P}<0.01)$.

Table 8: Effect of salt stress on blood sodium and potassium and its related hormones of pregnant Shami goats

\begin{tabular}{|c|c|c|c|c|c|c|c|}
\hline \multirow[t]{2}{*}{ Items } & \multirow{2}{*}{$\begin{array}{l}\text { Month of } \\
\text { pregnancy }\end{array}$} & \multicolumn{2}{|c|}{ Treatment (Tr) } & \multirow{2}{*}{$\begin{array}{l}\text { Overall } \\
\text { mean }\end{array}$} & \multicolumn{3}{|l|}{$\pm \mathrm{SE}$} \\
\hline & & $\mathrm{C}$ & $\mathbf{S}$ & & $\operatorname{Tr}$ & $\mathbf{M}$ & $\operatorname{Tr}^{*} \mathbf{M}$ \\
\hline \multirow[t]{2}{*}{ Sodium (mmol/1) } & $4^{\text {th }}$ & $133.80^{\mathrm{d}}$ & $156.77^{\mathrm{a}}$ & 145.28 & $1.24^{* *}$ & $1.24^{\mathrm{NS}}$ & $1.75^{* *}$ \\
\hline & $5^{\text {th }}$ & $141.60^{c}$ & $148.11^{b}$ & 144.85 & & & \\
\hline Overall mean & & $137.7^{b}$ & $152.44^{\mathrm{a}}$ & & & & \\
\hline Potassium & $4^{\text {th }}$ & $5.02^{c}$ & $6.37^{\mathrm{ab}}$ & $5.69^{\mathrm{B}}$ & $0.16^{*}$ & $0.16^{* *}$ & $0.23^{* *}$ \\
\hline$(\mathrm{mmol} / \mathrm{l})$ & $5^{\text {th }}$ & $6.92^{\mathrm{a}}$ & $6.58^{a}$ & $6.75^{\mathrm{A}}$ & & & \\
\hline Overall mean & & $5.97^{b}$ & $6.47^{\mathrm{a}}$ & & & & \\
\hline Osmolality & $4^{\text {th }}$ & $291.12^{\mathrm{d}}$ & $339.00^{\mathrm{a}}$ & 315.06 & $2.81^{* *}$ & $2.81^{\mathrm{NS}}$ & $3.97^{* *}$ \\
\hline (mOsmol/kg) & $5^{\text {th }}$ & $307.37^{c}$ & $324.81^{b}$ & 316.09 & & & \\
\hline Overall mean & & $299.25^{b}$ & $331.90^{a}$ & & & & \\
\hline \multirow[t]{2}{*}{$\operatorname{Renin}(\mathrm{ng} / \mathrm{ml})$} & $4^{\text {th }}$ & $2.90^{\mathrm{b}}$ & $3.60^{\mathrm{a}}$ & $3.25^{\mathrm{A}}$ & $0.11^{\mathrm{NS}}$ & $0.10^{* *}$ & $0.14^{* *}$ \\
\hline & $5^{\text {th }}$ & $2.00^{c}$ & $1.80^{c}$ & $1.90^{\mathrm{B}}$ & & & \\
\hline Overall mean & & 2.45 & 2.70 & & & & \\
\hline Aldosterone & $4^{\text {th }}$ & $27.00^{\mathrm{b}}$ & $23.00^{c}$ & $25.00^{\mathrm{B}}$ & $0.66^{* *}$ & $0.65^{* *}$ & $0.92^{* *}$ \\
\hline
\end{tabular}


C: fed on berseem hay and drank tap water, S: fed on salt-tolerant plant and drank saline water, A, B Means bearing different superscripts within the same column are significantly different $(\mathrm{P}<0.05),{ }^{a, b, c, d}$ Means bearing different superscripts within the same rows are significantly different $(\mathrm{P}<0.05), \mathrm{NS}=$ non-significant, ${ }^{*}=$ significant differences $(\mathrm{P}<0.05),{ }^{* *}=$ significant differences $(\mathrm{P}<0.01)$. Table 9: Minerals and its related hormones of kids born to pregnant goats ingest high salt intake.

\begin{tabular}{|c|c|c|c|c|c|c|c|}
\hline \multirow[t]{2}{*}{ Items } & \multirow{2}{*}{$\begin{array}{l}\text { Age } \\
\text { (month) }\end{array}$} & \multicolumn{2}{|c|}{ Treatment $(\mathrm{Tr})$} & \multirow{2}{*}{$\begin{array}{l}\text { Overall } \\
\text { mean }\end{array}$} & \multicolumn{3}{|l|}{$\pm \mathrm{SE}$} \\
\hline & & $\mathrm{C}$ & $\mathbf{S}$ & & $\operatorname{Tr}$ & $\mathbf{M}$ & $\operatorname{Tr}^{*} \mathbf{M}$ \\
\hline \multirow[t]{3}{*}{ Sodium (mmol/1) } & $2^{\text {nd }}$ & 137.80 & 146.68 & $142.24^{\mathrm{A}}$ & $0.98^{* * *}$ & $1.21^{*}$ & $1.71^{\mathrm{NS}}$ \\
\hline & $3^{\text {rd }}$ & 135.06 & 147.06 & $141.06^{\mathrm{A}}$ & & & \\
\hline & $4^{\text {th }}$ & 131.64 & 143.13 & $137.39^{\mathrm{B}}$ & & & \\
\hline Overall mean & & $134.83^{b}$ & $145.62^{\mathrm{a}}$ & & & & \\
\hline \multirow[t]{3}{*}{ Potassium (mmol/l) } & $2^{\text {nd }}$ & $5.15^{\mathrm{c}}$ & $7.52^{\mathrm{a}}$ & $6.33^{\mathrm{A}}$ & $0.11^{* *}$ & $0.14^{* *}$ & $0.20^{* *}$ \\
\hline & $3^{\text {rd }}$ & $5.63^{c}$ & $6.66^{\mathrm{b}}$ & $6.14^{\mathrm{A}}$ & & & \\
\hline & $4^{\text {th }}$ & $5.20^{c}$ & $5.66^{c}$ & $5.43^{\mathrm{B}}$ & & & \\
\hline Overall mean & & $5.33^{b}$ & $6.61^{\mathrm{a}}$ & & & & \\
\hline \multirow{3}{*}{$\begin{array}{l}\text { Osmolality } \\
(\mathrm{mOsmol} / \mathrm{kg})\end{array}$} & $2^{\text {nd }}$ & 299.25 & 321.46 & $310.36^{\mathrm{A}}$ & $2.29^{* *}$ & $2.81^{* *}$ & $3.97^{\mathrm{NS}}$ \\
\hline & $3^{\text {rd }}$ & 293.18 & 320.19 & $306.69^{\mathrm{A}}$ & & & \\
\hline & $4^{\text {th }}$ & 284.67 & 311.67 & $298.17^{\mathrm{B}}$ & & & \\
\hline Overall mean & & $292.37^{b}$ & $317.77^{\mathrm{a}}$ & & & & \\
\hline \multirow[t]{3}{*}{$\operatorname{Renin}(\mathrm{ng} / \mathrm{ml})$} & $2^{\text {nd }}$ & $2.90^{\mathrm{bc}}$ & $3.00^{\mathrm{b}}$ & $2.95^{\mathrm{A}}$ & $0.08^{* * *}$ & $0.10^{\text {** }}$ & $0.15^{* *}$ \\
\hline & $3^{\text {rd }}$ & $4.60^{\mathrm{a}}$ & $1.70^{\mathrm{d}}$ & $3.15^{\mathrm{A}}$ & & & \\
\hline & $4^{\text {th }}$ & $3.00^{\mathrm{b}}$ & $1.50^{\mathrm{d}}$ & $2.25^{\mathrm{B}}$ & & & \\
\hline Overall mean & & $3.50^{\mathrm{a}}$ & $2.06^{b}$ & & & & \\
\hline \multirow{3}{*}{$\begin{array}{l}\text { Aldosterone } \\
(\mathrm{pg} / \mathrm{ml})\end{array}$} & $2^{\text {nd }}$ & $41.28^{\mathrm{a}}$ & $19.00^{\mathrm{e}}$ & $30.14^{\mathrm{B}}$ & $0.61^{* *}$ & $0.75^{* *}$ & $1.06^{* *}$ \\
\hline & $3^{\text {rd }}$ & $32.50^{c}$ & $20.40^{\mathrm{e}}$ & $26.45^{\mathrm{C}}$ & & & \\
\hline & $4^{\text {th }}$ & $40.00^{\mathrm{ab}}$ & $26.80^{d}$ & $33.40^{\mathrm{A}}$ & & & \\
\hline Overall mean & & $37.92^{a}$ & $22.06^{b}$ & & & & \\
\hline
\end{tabular}

C: fed on berseem hay and drank tap water, S: fed on salt-tolerant plant and drank saline water. ${ }^{\text {A, B, C }}$ Means bearing different superscripts within the same column are significantly different $(\mathrm{P}<0.05)$, , b, c, d,e Means bearing different superscripts within the same rows are significantly different $(\mathrm{P}<0.05), \mathrm{NS}=$ non-significant, ${ }^{*}=$ significant differences $(\mathrm{P}<0.05),{ }^{* *}=$ significant differences $(\mathrm{P}<0.01)$

because of their role in maintaining the electrolyte balance and osmolality of blood and other body fluids. Similarly, da Silva et al. (2003) found in Shami goats that fed high salt tolerant plant and drank saline water an increased plasma osmolality and sodium levels.

Data presented in Table (9) showed that fetal plasma osmolality and sodium were also enhanced by maternal salt intake during pregnancy. Blood osmolality and sodium levels which observed in the fetus could be associated with two major sources. One of them was the salt from the maternal circulation cross the placenta; the other could be related to fetal own regulations when $\mathrm{Na}^{+}$levels were increased.

Sodium $(\mathrm{Na})$ and potassium are Known to be found in high concentration in salt tolerant plant (El-Shaer, 2010), however, excess intake of these electrolytes is accompanied by their excess excretion through the kidneys (Neatherly, 1980). So, sodium retention and the increase in extracellular volume are the main characteristics of pregnancy that are very important to maintenance of mother and fetal growth (Davison and Lindhemer, 1989). Thus osmolality is significantly increased in the high salt ingestion animals by stimulating the kidneys through osmoreceptors to maintain water and electrolyte balance, when there is excess present, then osmoreceptors stimulate the kidney to decrease sodium reabsorption.

Renin angiotensin system (RAS) controls the regulation of the salt and water balance (Fitzsimons 1998), a system that involves hormones such as renin, angiotensin (even I and II), and aldosterone-controlling sodium retention as much as arginine vasopressin (AVP)-controlling water reabsorption. The present study clarify that there were significant decreases in aldosterone concentrations in both pregnant 
goats and their offspring ingesting high salt intake than that found in the control groups. In pregnant does drank saline water (S group), the decrease in plasma renin activity resulted in regulation of salt and water balance, and in turn decreases the production of angiotensin II and finally the secretion of aldosterone (Digby et al., 2008; Chadwick et al., 2009).

Data obtained in this study revealed that the most serious adaptive mechanism that helped pregnant Shami goats to successfully complete pregnancy may be the reduction in aldosterone concentration while fed on Alfalfa and drank saline water. Therefore, these goats were probably able to bypass obstacles such as hypertension, or neonatal mortalities by decreasing their plasma aldosterone concentration than that in the control animals.

\section{CONCLUSIONS}

Salt tolerant plant could be used as alternative feed resource for Shami goats with or without drinking saline drinking water since they can tolerate a high salt intake and live under harsh condition of marginal regions with minimum weight loss. Moreover, their offspring will be programmed to alter their adaptive response to grow well under these harsh conditions.

\section{ACKNOWLEDGMENTS}

The authors are thankful to project entitled "Improving the livelihood of smallholder farmers through optimal utilization of saline agriculture in Sinai" for supporting and facilitating this research work.

\section{CONFLICT OF INTEREST}

The authors declare that they have no conflict of interest with respect to the research, authorship, and/or publications of this article. The authors declare that they have no competing interests.

\section{AUTHOR'S CONTRIBUTION}

Dr. Moharram Fouad E1-Bassiony designed the experiment, statistical analysis, tabulation of experimental data, manuscript writing, commenting and approval. Dr. Ahmed Sobhy El-Hawy designed the experiment, helped in field study, article writing and revision. Ashgan Mohamed ElLamei collected data, tabulation of experimental data and article writing. Reda Abdel-Azeem Abd-Ellattif facilitates the field study, manuscript writing and revision.

\section{REFERENCES}

-A.O.A.C (1985). Official Methods of Analysis. 14 ${ }^{\text {th }}$ Ed.,
Advances in Animal and Veterinary Sciences

Association of Official Analytical Chemists, Washington, D.C., USA.

-Abdel-Halim AM (2003). Studies of Some Anti-Nutritional Factors Affecting Forage Utilization by Ruminants. Ph.D. Thesis, Fac. Sci., Ain Shams Univ., Egypt.

-Abdel-Rahman AM, Abou-Ashour AM, Abdou FH, El-Sherif MMA, Hassan AH (2000). Effect of drinking natural saline water on some physiological aspects of California rabbits. 5th Vet. Med. Zag. Conference (12-14 Sept. 2000) Sharm El-Sheikh, 94-100.

-Amstalden M, Garcia MR, Williams SW, Stanko RL, Nizielski S, Morrison ECD, Keisler DH, Williams GL (2000). Leptin gene expression, circulating leptin, and luteinizing hormone pulsatility are acutely responsive to short-term fasting in prepubertal heifers: relationships to circulating insulin and insulin-like growth factor I. Biol. Reprod. 63: 127-133 https://doi.org/10.1095/biolreprod63.1.127

-Awemu EM, Nwakalo LN, Abubakar BY (2002). The biological productivity of the Yankasa sheep and the Red Sakoto goat in Nigeria., Ph.D.thesis, Dept. of Animal Science, University of Nigeria, Nsukka, Nigeria.

-Ban-Tokuda T, Orden EA, Barrio AN, Lapitan RM, Delavaud C, Chilliard Y, Fujihara I, Cruz LC, Homma H, Kanai Y (2007). Effects of species and sex on plasma hormone and metabolite concentrations in crossbred Brahman cattle and crossbred water buffalo. Livest. Sci. 107: 244-252. https:// doi.org/10.1016/j.livsci.2006.09.023

-Blache D, Grandison MJ, Masters DG, Dynes RA, Blackberry MA, GA Martin (2007). Relationships between metabolic endocrine systems and voluntary feed intake in Merino sheep fed a high salt diet. Australian J. Experimen. Agric. 47: 544-550. https://doi.org/10.1071/EA06112

- Block SS, Rhoads RP, Bauman DE, Ehrhardt RA, McGuire MA, Crooker BA, Griinari JM, Mackle TR, Weber WJ, Van Amburgh ME, Boisclair YR (2003). Demonstration of a role for insulin in the regulation of leptin in lactating dairy cows. J. Dairy Sci. 86: 3508-3515. https://doi.org/10.3168/ jds.S0022-0302(03)73955-1

- Briffa JF, McAinch AJ, Romano T, Wlodek ME, Hryciw DH (2015). Leptin in pregnancy and development: a contributor to adulthood disease. Am.J. Physiol. Endocrinol.Metab. 308: E335-E350. https://doi.org/10.1152/ajpendo.00312.2014

- Chadwick MA, IH Williams, PE Vercoe, D.K. Revell1 (2009a). Feeding pregnant ewes a high-salt diet or saltbush suppresses their offspring's postnatal renin activity. Animal. 3:7, 972979. https://doi.org/10.1017/S175173110900425X

- Coles EH (1986). Veterinary Clinical Pathology. $4^{\text {th }}$ Ed. Sunders W. B. Company, Philadelphia, USA.

- Curtis KS, Krause EG Wong DL, RJ Contreras (2004). Gestational and early postnatal dietary $\mathrm{NaCl}$ levels affect $\mathrm{NaCl}$ intake, but not stimulated water intake, by adult rats. American Journal of Physiology - Regulatory, Integrative and Comparative Physiology. 286: R1043-R1050. https:// doi.org/10.1152/ajpregu.00582.2003

-Da Silva AA, de Noronha IL, de Oliveira IB, Malheiros DM, Heimann GC (2003). Renin angiotensin system function and blood pressure in adult rats after perinatal salt overload. Nutrition, Metabolism and Cardiovascular Disease. 13: 133139. https://doi.org/10.1016/S0939-4753(03)80172-2

-Davison JM, Lindheimer MD (1989). Volume homeostasis and osmoregulation in human pregnancy. Baillieres Clin. Endocrinol.Metab. 3(2): 451-472. https://doi.org/10.1016/ S0950-351X(89)80011-4 
- Digby SN, Masters DG, Blache D, Hynd PI, DK Revell (2010): Offspring born to ewes fed high salt during pregnancy have altered responses to oral salt loads. Animal. 4:1, 81-88 https://doi.org/10.1017/S1751731109990772

- Digby SN, Masters DG, Blache D, Blackberry MA, Hynd PI, DK Revell (2008). Reproductive capacity of Merino ewes fed a high-salt diet. Animal. 2:1353-1360. https://doi. org/10.1017/S1751731108002449

- Duncan DB (1955). Multiple range and multiple F test. Biometrics. https://doi.org/10.2307/3001478

-El-Shaer HM (2006). Halophytes as cash crops for animal feeds in arid and semi-ard regions. In: Öztürk M, Waisel Y, Khan MA, Görk G, editors. Biosaline agriculture and salinity tolerance in Plants. Basel: BirkhauserVerlag; pp:117-128. https://doi.org/10.1016/j.smallrumres.2010.01.010

-El-Shaer HM (2010). Halophytes and salt-tolerant plants as potential forage for ruminants in the Near East region. Small Rumin. Res. 91:3-12 https://doi.org/10.1016/j. smallrumres.2010.01.010

-El-Tayeb EE (2006). Effect of Salinity of Drinking Water and Dehydration on Thermoregulation, Blood and Urine Composition in Nubian Goats. M.Sc. Thesis, Fac. Vet., ElKhartoum Univ., El-Khartoum, Sudan.

- Fayed, Afaf M, El-Essawy, Abeer M, Eid EY,Helal HG, Abdou, Ahlam R, El-Shaer HM (2010). Utilization of alfalfa and atriplex for feeding sheep under saline conditions of South Sinai, Egypt. J. Americ. Sci. 6 (12) 1447-1461.

-Fitzsimons JT (1998). Angiotensin, thirst, and sodium appetite. Physiolog. Rev. 78: 585-589. https://doi.org/10.1152/ physrev.1998.78.3.583

-Flores JO (2002). Gale Encyclopedia of Medicine, Published December, 2002 by the Gale Group. http://www.hrpca.org/ liverfunction.htm

- Houseknecht KL, Portocarrero CP, Ji S, Lemenager R, Spurlock ME (2000). Growth hormone regulates leptin gene expression in bovine adipose tissue: correlation with adipose IGF-I expression. J. Endocrinol. 172, 1-19. https:// doi.org/10.1677/joe.0.1640051

-Hussein NM (1987). Hematological studies on sheep drinking salty water. M. Sc. Thesis, Faculty of Science, Al - Azhar Univ.

-Huszenicza g, Fekete S, Szigeti G (2002). Ovarian consquences of low dose peroral Fusarium (T-2) Toxin in a ewe and heifer model. Theriogenology, 53: 1631-1639. Inc., Cary, N.C., USA. https://doi.org/10.1016/S0093-691X(00)00303-4

-Ibrahim IA, Abd-Alla OA, El-Nahia AM (1991). Biochemical and hematological studies in male buffalo- calves drinking well's water. Egypt. J. Comp. Pathol. Clin. Pthol. 4 (2) : 237 $-244$.

-Ibrahim SMN (1995). Clinicopathological studies in goats drinking salty water under desert conditions. M. Sc. (clinical pathology), V. Sc. Cairo Univ.

-Kaneko JJ (1989). Clinical biochemistry of domestic animals. $4^{\text {th }}$ ed. Academic Press Inc., USA.

- Kearl LC (1982). Nutrient Requirements of Ruminants in Developing Countries. International Feedstuffs Institute, Utah Agricultural Experiment Station, Utah State Univ., Logan, Utah, USA.

-Magistrelli D,Dimel P, Rosi F (2008). Leptin, insulin and ghrelin levels in goat milk and in plasma of suckling kids. Small Ruminate. Res. 79:38-Leptin, insulin and ghrelin levels in goat milk and in plasma of suckling kids. Small Rumin. Res. 79:38-https://doi.org/10.1016/j.smallrumres.2008.07.004

- Marie M, Findlay PA, Thomas L, Adam CL (2001). Daily patterns of plasma leptin in sheep. Effects of photoperiod and food intake.J. Endocrinol. 170: 277-86. https://doi. org/10.1677/joe.0.1700277

-Martin-Gronert MS, Ozanne SE (2006). Maternal nutrition during pregnancy and health of the offspring. Biochemical Society Transactions 34: 779-782. https://doi.org/10.1042/ BST0340779

-Milne DB (1996). Trace elements. In: Tietz Fundamentals of Clinical Chemistry. (Eds. Burtis, C.A. and Ashood, E.R.), pp. $485-496$.

-Mohamed MO, CJC Phillips (2003). The effect of increasing salt intake of pregnant dairy cows on the salt appetite and growth of their calves. Anim. Sci. 77: 181-185. https://doi. org/10.1017/S1357729800053777

- Mtenga LA, Owen E, Muhikambele VRM, Kifaro GC, Sendalo DCS, Massawe NF, Kiango SM, Nkungu DR (1992). Growth and partition of fat depots in male British Saanen goats. Proceedings of the Third Biennial Conference of the African Small Ruminant Research Network, UICC, Kampala, Uganda, 5-9 December 1994.

- Neathery MW (1980). Chloride metabolism in cattle. In: Proceedings of the Georgia Nutrition Conference, pp. 137.

-SAS Institute (2004). Statistical Analysis System, STAT/ user's guide, Release 9.1, SAS Institute, Cary NC. USA.

- Scarth JP (2006). "Modulation of the growth hormone-insulinlike growth factor (GH-IGF) axis by pharmaceutical, nutraceutical and environmental xenobiotics: an emerging role for xenobiotic-metabolizing enzymes and the transcription factors regulating their expression. A review". Xenobiotica. 36 (2-3): 119-218. https://doi. org/10.1080/00498250600621627

- Shaker YM, NH Ibrahim, FE Younis, HM El Shaer (2014). Effect of feeding some salt tolerant fodder shrubs mixture on physiological performance of Shami goats in Southern Sinai, Egypt. J. Am. Sci. 10(2s): 66-77.

-Stephens TW, Basinski M, Bristow PK, Bue-Valleskey JM, Burgett SG, Craft L, Hale J, Hoffmann J, Hsiung HM, Kriauciunas A (1995). The role of neuropeptide $Y$ in the antiobesity action of the obese gene product. Nature. 12. 377(6549): 530-2. https://doi.org/10.1038/377530a0

- Tata JR, Widnell CC (1966). Ribonucleic and synthesis during the early action of Hormone. Biochemistry. 98: 604. https:// doi.org/10.1042/bj0980604

- Thomas L., Wallace JM, Aitken RP, Mercer JG, Trayhurn P, Hoggard N (2001). Circulating leptin during ovine pregnancy in relation to maternal nutrtion, body composition and pregnancy outcome.J. Endocrinol. 169: 465-76. https:// doi.org/10.1677/joe. 0.1690465

- Tokuda T, Kimura D, Fujihara T (2001). The relationships between leptin and insulin in blood plasma of growing lambs. Anim. Sci. 73: 71-76. https://doi.org/10.1017/ S1357729800058069

-Wynne-Edwards KE, Weil ZM (2019). Encyclopedia of Animal Behavior (Second Edition). 